\title{
Flypaper Effect of General Allocation Fund (DAU) And Human Development Index (IPM) (A Case Study In Regencies and Municipality In Bali)
}

\author{
Ida Bagus Raka Suardana \\ Faculty of Economic and Business, UNDIKNAS University, Indonesia \\ I Putu Astawa \\ Tourism Business Management, State Polytechnic Of Bali, Indonesia
}

\begin{abstract}
The main objective of this research is to show the relationship between General Allocation Fund (DAU), Own-Source Revenue (PAD), Capital Expenditure, Economic Growth, Human Development Index (IPM), and Income per Capita of regencies/municipality in Bali. The other objective is to provide empirical evidence on the occurrence of flypaper effect in DAU and PAD on Capital Expenditure. Data is taken from audited local budget and revenue report and from Bureau of Statistic (Badan Pusat Statistik-BPS) Bali Province. Result of analysis indicates that the variable of DAU and PAD is positively related to Capital Expenditure, Capital Expenditure is positively related to Economic Growth, Capital Expenditure is negatively related to Income Per Capita, and Capital Expenditure is positively related to Human Development Index. DAU and PAD are separately influenced Capital Expenditure, but the coefficient of PAD is greater than DAU. It indicates that there is no flypaper effects occurred on Capital Expenditure. Flypaper effect is defined as local response (expenditure) that is greater than transfer. The results still require confirmation through future researches.
\end{abstract}

Keywords: Capital Expenditure, Economic Growth, Flypaper Effect, General Allocation Fund (DAU), Human Development Index (IPM), Income per Capita, Own-source Revenues (PAD).

\section{INTRODUCTION}

The implementation of regional autonomy in Indonesia since 2004 is a reformation in the relationship between central government and local government in order to decrease dependency of local to central. Through regional autonomy, regions are not only implementing the instructions given by central government but also demanded to develop creativity and innovation of regional potential that less optimized before the implementation of autonomy $[12,18]$. In addition, the autonomy has required local government to be more independent. One of indications for the independence is the increase in the contribution of own-source revenue (Pendapatan Asli Daerah-PAD) in regional funding [8,3].

One of obstacles faced in the implementation of regional autonomy is fiscal gap among regions [17]. Result of research by Adi and Laras \& Adi $[3,27]$ shows differences in the readiness of regions in entering regional autonomy era. To overcome the obstacle, central government gives assistance (transfer) to local government in form of, for example, general allocation fund (Dana Alokasi Umum-DAU) and specific allocation fund (Dana Alokasi Khusus-DAK). Baskaran [6] and Gan [16] concluded that DAU is an important source of income for local government since it can be distributed to overcome horizontal and vertical gap in income among regions. Bird \& Smart [9] in their research concluded that in general, the role of DAU and DAK is similar to grant. Based on both giver and receiver's viewpoint all resources distributed in DAU will be 
set in a stable but flexible way, which is a percentage of central tax adjustable for every few years.

Lewis [29] concluded that local government has the authority to set regional regulation on local tax and levies. The strategic role of local tax and levies has given significant contribution to source of revenue of PAD [4]. This role, however, is not strong enough in supporting overall regional budget (Anggaran Pendapatan dan Belanja Daerah-APBD). The demand for changing in expenditure structure is getting stronger, especially in regions with low fiscal capacity $[22,19]$. In order to increase regional independency local government is required to optimize their own revenue potential and one of way in doing it is by giving bigger proportion of capital expenditure for development in productive sectors in the regions. Conducted a research on the impact of fiscal decentralization on economic growth and income inequality among regions in Indonesia and found that the impact could either be positive or negative [43].

The industrial infrastructure development affect the increase in own-source revenue (local tax) [44]. Higher capital investment level is expected to be able to increase the quality of public services and in turn, it able to increase public participation level in development that reflected in the increase in PAD [33]. Economic growth is often measured by gross domestic product (GDP). Another measurement, however, that can be used to measure economic growth is income per capita [25]. Bali Province is one of 34 provinces in Indonesia and it consists of 8 regencies and 1 municipality. The expenditure of the regions has increased every year since 2010 to 2014. The increase, however, is not in line with the increase in own-source revenue (PAD).

The aim of the research was to find out and analyze flypaper effect of general allocation fund (DAU) and own-source revenue (PAD) on capital expenditure (BM) and on regional economic growth (PED), income per capita (PPK) and human development index (IM) of regencies and municipality in Bali.

\section{LITERATURES REVIEW AND HYPOTHESES DEVELOPMENT The Influence of General Allocation Fund (DAU) on Capital Expenditure (BM)}

In some regions, the role of DAU is significant since regional expenditure policy is dominated by the number of DAU than PAD [37]. With DAU aiming for regional expenditure funding, which is unable to be funded through own-source revenue, regions try to create expenditure planning that tends to be optimistic in hoping to gain higher DAU. A study [28] found empirical evidence that in long term, transfer influences capital expenditure and the decrease in the number of transfer will cause decrease in capital expenditure.

Prakoso [35] found the same empirical finding indicating that the number of capital expenditure is influenced by DAU received from central government. Research result of Adi \& Harianto [2] confirmed the tendency. They found that regional independency is not getting better; on the contrary, the dependency of local government on central government's DAU transfer is higher. Studies by Maimunah [32] in Sumatera Island using sample of 95 regencies/municipalities in 2004, Darwanto \& Yustikasari [11] in regencies/municipalities in Aceh, and Christy \& Adi (2008) and Andirfa (2008) in regencies/municipalities in Aceh concluded that DAU had positive influence on regional capital expenditure. A research [45], however, found different empirical evidence that DAU transfer by central government had no significant influence on regional capital expenditure. 
The above various researches give strong indication that regional expenditure behavior, especially capital expenditure, will be strongly influenced by central government transfer (DAU). Based on the description, following research hypothesis is developed:

Hypothesis 1 (H1): The higher the general allocation fund (DAU), the higher the capital expenditure (BM)

\section{The Influence of Own-source Revenue (PAD) on Capital Expenditure (BM)}

The ability of regions to provide funding from their own region will depend on the ability to realize the economic potential into forms of economic activity that able to create revolving fund for regional sustainable development. Central government expects local government to optimize their potential to reduce fiscal gap [38].

Some studies found empirical evidence on the linkages between own-source revenue (PAD) and regional capital expenditure. Studies by Maimunah [32] in Sumatera Island with sample of 95 regencies/municipalities in 2004, Darwanto \& Yustikasari [11] in regencies/municipalities in Aceh, Andirfa (2009) in regencies/municipalitis in Aceh, and Yudani [45] in Bali Province found empirical evidence that PAD has significant influence on regional capital expenditure.

Based on the above studies, a research hypothesis can be developed as follow:

Hypothesis 2 (H2): The higher the own-source revenue (PAD), the higher the capital expenditure (BM)

\section{The Influence of Capital Expenditure (BM) on Regional Economic Growth (PED)}

A research [23] gave empirical evidence that capital expenditure has positive influence on regional economic growth (PED). The fundamental requirement for economic development is level of development capital procurement that equal to population growth. The capital formation should be broadly defined to cover all expenditures that are increasing productivity [21]. Based on PP (government regulation) No. 71, 2010 on Governmental Accounting Standard (Standar Akuntansi Pemerintah-SAP) and a research on the influence of capital expenditure (BM) on regional economic growth (PED), a research hypothesis can be developed as follow:

Hypothesis 3 (H3): The higher the capital expenditure (BM), the higher the regional economic growth (PED)

\section{The Influence of Capital Expenditure (BM) on Income per Capita (PPK)}

According to Kuncoro [23], the development of facilities and infrastructures by local government has positive impacts on economic growth. Sustainable increase in public sector services will increase public facilities and infrastructure, government investment as well as improvement in education, health, and other supporting facilities. Ismerdekaningsih \& Rahayu [21] stated that government spending in form of infrastructures expenditure should always be adjusted to population growth so that it gives increase in the productivity of society. With the increase in infrastructure and infrastructure improvement by central government, it is hoped that it encourages economic growth in the area. Regional economic growth will stimulate increase in people's income in the related area and along with it income per capita will also increase [30]. 
A research [20] gave different result where allocation of capital expenditure of local government has significant negative influence on income per capita. Based on the research on the influence of capital expenditure (BM) on income per capita (PPK), following research hypothesis is developed:

Hypothesis 4 (H4): The higher the capital expenditure (BM), the higher the income per capita (PPK)

\section{The Influence of Capital Expenditure (BM) on Human Development Index (IPM)}

Capital expenditure (BM) consisting of capital expenditure of land, equipment \& machineries, buildings \& constructions, roads, irrigation \& network, and other physical capital expenditures is used to increase human development index (IPM) of the local society. IPM is measured by: 1) length of life, 2) level of knowledge, and 3) decent living standard. Capital expenditure is expected to increase IPM through improvement in various above indicators.

The influence of capital expenditure (BM) on human development index (IPM) and concluded that the amount of capital expenditure (BM) allocation has positive influence on human development index (IPM) [10,31]. However, gave different result where capital expenditure has no significant influence on IPM [40]. Based on the research on the influence of capital expenditure (BM) on human development index (IPM), a research hypothesis can be developed as follow:

Hypothesis 5 (H5): The higher the capital expenditure (BM), the higher the human development index (IPM)

\section{Flypaper Effect in the influence of DAU and PAD on Capital Expenditure (BM)}

The amount of general allocation fund (DAU) and own-source revenue (PAD) has significant positive influence on regional expenditure [32]. In the research, flypaper effect was found that influence the prediction of regional expenditure in the future period. Another finding is there was no flypaper effect on regional expenditure of education sector; on the contrary, flypaper effect occurred in regional expenditure for health and public works sectors.

A research [28] gave empirical evidence on the existence of flypaper effect in long term for sample of municipalities in Italy. They stated that local governments consistently increase their expenditure more with respect to increase in State transfer rather than increase in own revenues. Another study that supports the presence of flypaper effect in responding DAU on regional expenditure is a research [1] where flypaper effect occurred in responding DAU on regional expenditure in the island of Java and Bali.

Another research conducted by Kusumadewi \& Rahman [26] using sample data of 270 regencies/municipalities in Indonesia in the period of 2001 to 2004 found empirical evidence that flypaper effect was occurred in responding DAU and PAD on regional expenditure of regencies/municipalities in Indonesia for the period. A research [36] using data of regencies and municipalities in Indonesia in the period of 2006-2008 found different result that flypaper effect occurred in municipalities/regencies in Java but not for municipalities/regencies outside the Java Island due to the differences in income potential between Java and outside Java.

Based on those researches, a research hypothesis can be developed as follow: Hypothesis 6 (H6): Flypaper effect is occurred in the influence of general allocation fund (DAU) and own-source revenue (PAD) on capital expenditure (BM) 


\section{RESEARCH METHOD}

Framework in the research was conducted through processing of data on DAU, PAD, regional capital expenditure, regional economic growth, regional income per capita, and IPM of regencies and municipality in Bali Province in 2010 to 2014. All data was secondary data and processed with AMOS (Path Analysis) Version 20 program. Data used in the research was population data, which were all regencies/municipality in Bali Province. The regencies consisted of: Badung, Gianyar, Buleleng, Jembrana, Klungkung, Tabanan, Bangli and Karangasem; whereas the city is Denpasar.

\section{Identification of Variables}

Exogenous Variable: DAU $\left(\mathrm{X}_{1}\right)$ and PAD $\left(\mathrm{X}_{2}\right)$ from 2010 to 2014 of regencies/municipality in Bali Province contained in the Report of Regional Budget (APBD) Realization audited by the Audit Board of the Republic of Indonesia (BPK-RI).Moderating Variable: Capital expenditure $\left(\mathrm{Y}_{1}\right)$ from 2010 to 2014 of regencies/municipality in Bali Province contained in the Report of APBD Realization audited by BPK-RI. Endogenous Variable: regional economic growth $\left(\mathrm{Y}_{2}\right)$, income per capita $\left(\mathrm{Y}_{3}\right)$, and IPM ( $\left.\mathrm{Y}_{4}\right)$ of regencies/municipality in Bali Province from 2010 to 2014 contained in Bureau of Statistic (BPS) Report of Bali Province [7].

\section{Operational Definition}

DAU $\left(\mathrm{X}_{1}\right)$ is the transfer of central government to local government determined by the regions' fiscal needs and fiscal capacity. Own-source revenue (PAD) $\left(\mathrm{X}_{2}\right)$ is the realization of local tax income, levies income, local wealth management result and other legitimate PAD.

Capital expenditure $\left(\mathrm{Y}_{1}\right)$ is the realization of expenditure for land, equipment and machineries, buildings and constructions, roads, irrigation and network, other fixed assets and other assets. Regional economic growth $\left(\mathrm{Y}_{2}\right)$ is the level or rate of economic growth of each regencies/municipality calculated based on gross national product (GNP) in form of gross domestic product (PDRB). Income per capita $\left(\mathrm{Y}_{3}\right)$ is gross domestic product (PDRB) of each regions divided by the number of population of each regencies/municipality in Bali Province. Human development index $\left(\mathrm{Y}_{4}\right)$ is the simple average of the three components:

$$
\mathrm{IPM}=1 / 3\left(\text { Index } \mathrm{X}_{1}+\operatorname{Index} \mathrm{X}_{2}+\operatorname{Index} \mathrm{X}_{3}\right)
$$

$X_{1}=$ length of life, $X_{2}=$ level of education, and $X_{3}=$ level of decent life

\section{DATA ANALYSIS TECHNIQUE}

The analysis technique used in the research was qualitative technique with path analysis to find out about the relationship between variables [39]. The analysis was conducted using Software AMOS version 20. Path analysis of variables of the influence of DAU, PAD, and capital expenditure (BM) on economic growth (PED), income per capita (PPK), and IPM into a structural equation in direct effect are as follow:

\begin{tabular}{|c|c|c|c|}
\hline DAU & $\rightarrow$ & $\mathrm{BM}$ & $=\gamma_{1} X_{1}+\xi_{1}$ \\
\hline PAD & $\rightarrow$ & $\mathrm{BM}$ & $=\gamma_{1} X_{2}+\xi_{1}$ \\
\hline $\mathrm{BM}$ & $\rightarrow$ & PED & $=\gamma_{2} Y_{1}+\xi_{2}$ \\
\hline BM & $\rightarrow$ & PPK & $=\gamma_{3} Y_{1}+\xi_{3}$ \\
\hline BM & $\rightarrow$ & IPM & $=\gamma_{4} Y_{1}+\xi$ \\
\hline
\end{tabular}


Hypothesis one to five (based on the above variable relationship) would be tested with AMOS (path analysis). The flypaper effect test (hypothesis six) was conducted by comparing the effect of DAU on BM to the effect of PAD on BM. Flypaper effect will occur with the following conditions: (1) if the effect (coefficient value) of DAU on BM is higher than the effect of PAD on $\mathrm{BM}$ and both are significant, or (2) PAD is not significant [32].

\section{RESEARCH RESULT AND ANALYSIS}

Refer to hypothesis one to six, data on DAU, PAD, BM, PED, PPK and IPM would be processed with path analysis. The result of the development of path diagram built based on theoretical study that explains causal relationship between variables in the research is described in Appendix 1. Result of model testing that was conducted using regression coefficient is described in Appendix 2. Based on the criteria of chi square test, relative chi square, RMSEA, GFI, CFI, and goodness of fit value of the result of data processing using AMOS version 20.0, model feasibility test is described in Appendix 3.

\section{The Influence of DAU on Capital Expenditure (BM)}

Result of data processing shows the value of standardized regression weight of 0.16 and significance of less than 0.05. It means that DAU had significant positive influence on capital expenditure of regencies/municipality in Bali Province. An increase in DAU of 1 unit is only able to increase capital expenditure (BM) of 0.16 unit [42.43]

The result supports the research $[28,35,32,20,11,10,5]$ that stated that DAU had significant positive influence on capital expenditure (BM). The result, however, is in conflict with the result of Yudani's (2008) research that found that central government transfer (DAU) had no significant influence on regional capital expenditure. The amount of DAU given by central government to regencies/municipality in Bali for 2010 to 2014 influenced the capital expenditure of the regencies/municipality. The contribution of DAU allocation on BM was only 0.16 .

Hypothesis $1\left(\mathrm{H}_{1}\right)$ stated that the higher the DAU, the higher the BM. The result of path analysis shows coefficient value of 0.16 . It indicates that DAU had significant positive influence on BM. The result accepts the first hypothesis.

\section{The Influence of PAD on Capital Expenditure (BM)}

Result of data processing shows the value of standardized regression weight of 0.79 and significance of less than 0.05. It means that PAD had significant positive influence on capital expenditure (BM) of regencies/municipality in Bali Province. An increase in PAD of 1 unit will be able to increase capital expenditure (BM) of 0.79 unit.

The result supports the research $[45,32,11,5]$ that stated that PAD has significant positive influence on capital expenditure (BM). The amount of PAD obtained by regencies/municipality in Bali Province during 2010-2014 had great influence on the amount of capital expenditure of regencies/municipality in Bali Province.

Hypothesis $2\left(\mathrm{H}_{2}\right)$ stated that the higher the PAD, the higher the BM. Result of path analysis shows coefficient value of 0.79 . It indicates that PAD had significant positive influence on BM. The result accepts the second hypothesis.

\section{The Influence of Capital Expenditure (BM) on Regional Economic Growth (PED)}

Result of data processing shows the value of standardized regression weight of 0.87 and significance of less than 0.05. It means that BM had significant positive influence on PED of 
regencies/municipality in Bali Province. An increase in BM of 1 unit will be able to increase 0.87 unit of regional economic growth (PED). The result supports the research $[23,21$ that stated that capital expenditure (BM) had significant positive influence on regional economic growth (PED). The amount of BM of regencies/municipality in Bali Province during 2010-2014 had great influence on the amount of regional economic growth (PED) of regencies/municipality in Bali Province.

Hypothesis $3\left(\mathrm{H}_{3}\right)$ stated that the higher the BM, the higher the PED. Result of path analysis shows coefficient value of 0.87 . It indicates that BM had significant positive influence on PED. The result accepts the third hypothesis.

\section{The Influence of Capital Expenditure (BM) on Income per Capita (PPK)}

Result of data processing shows the value of standardized regression weight value -0.06 and significance of less than 0.05. It means that capital expenditure (BM) had insignificant negative influence on PPK of regencies/municipality in Bali Province. Every increase in BM of 1 unit will decrease 0.87 unit of PPK.

The result supports the research [20] that the allocation of capital expenditure of local government had insignificant negative influence on income per capita. It is, however, in conflict with the research $[23,21]$ that stated that capital expenditure (BM) had significant positive influence on income per capita (PPK). The amount of BM of regencies/municipality in Bali Province during 2010-2014 had no influence on the amount of income per capita (PPK) of regencies/municipality in Bali Province.

Hypothesis $4\left(\mathrm{H}_{4}\right)$ stated that the higher the BM, the higher the PPK. Result of path analysis shows coefficient value of -0.06 . It indicates that BM had insignificant negative influence on PPK. The result rejects the fourth hypothesis.

\section{The Influence of Capital Expenditure (BM) on Human Development Index (IPM)}

Result of data processing shows the value of standardized regression weight of 0.64 and significance of less than 0.05. It means that capital expenditure (BM) had significant positive influence on IPM of regencies/municipality in Bali Province. An increase in BM of 1 unit will cause the increase of 0.64 unit in IPM. The result supports the research $[10,31]$ that stated that the allocation of capital expenditure had significant influence on IPM. It is, however, in conflict with [40] research. The amount of BM of regencies/municipality in Bali Province during 20102014 had great influence on the amount of human development index (IPM) of regencies/municipality in Bali Province.

Hypothesis $5\left(\mathrm{H}_{5}\right)$ stated that the higher the BM, the higher the IPM. Result of path analysis shows coefficient value of 0.64 . It indicates that BM had significant positive influence on IPM. The result accepts the fifth hypothesis.

\section{Flypaper Effect in the influence of DAU and PAD on Capital Expenditure (BM)}

Result of data processing shows the value of standardized regression weight of DAU of 0.16 and significance of less than 0.05. PAD, on the other hand, had value of 0.79 and significance of less than 0.05. It means that DAU and PAD were equally significant on BM. However, the value of standardized regression weight of PAD (0.79) was higher than those of DAU (0.16). Based on the criteria of the occurrence of flypaper effect, which are (1) the effect (coefficient value) of DAU on BM is bigger than the effect of PAD and both are significant or (2) PAD is not significant 
(Maimunah, 2008), it can be concluded that there was no flypaper effect of DAU on BM of regencies/municipality in Bali Province.

The result supports the research [36], where there was no flypaper effect in outside Java regions (difference in regions potential). No occurrence of flypaper effect is due to the average of PAD of regencies/municipality in Bali Province was categorized as high category PAD [23,24,25]. 37 observation data were categorized as high PAD where the level of fiscal autonomy (DOF) is higher than 5\%, whereas only 8 observations with PAD in low category.

The result is in conflict with the research [28,1,26,32] that stated that flypaper effect was occurred in responding DAU and PAD on regional capital expenditure.

Hypothesis $6\left(\mathrm{H}_{6}\right)$ stated that flypaper effect is occurred in the influence of general allocation fund (DAU) and own-source revenue (PAD) on capital expenditure (BM) of regencies/municipality in Bali Province in 2010 to 2014 is rejected based on the research result.

\section{CONCLUSION}

First, based on hypothesis test, first hypothesis was accepted where the amount of DAU had significant positive influence on capital expenditure. Second, based on hypothesis test, second hypothesis was accepted where the amount of PAD had significant positive influence on capital expenditure. Third, based on hypothesis test, third hypothesis was accepted where the amount of capital expenditure had significant positive influence on regional economic growth (PED). Fourth, based on hypothesis test, first hypothesis was rejected where the amount of DAU had insignificant negative influence on income per capita (PPK). Fifth, based on hypothesis test, fifth hypothesis was accepted where the amount of capital expenditure (BM) had significant positive influence on human development index (IPM). The sixth research purpose was to find out the occurrence of flypaper effect in general allocation fund (DAU) and own-source revenue (PAD) on capital expenditure (BM). The test result was rejecting the sixth hypothesis since flypaper effect did not occur in general allocation fund (DAU) and own-source revenue (PAD) on capital expenditure (BM).

\section{References}

Abdullah, Sukriy \& Halim, Abdul. (2013), The Influence of General Allocation Fund (DAU) and Own-Source Revenue (PAD) on Regional Government Expenditure. A Case Study in Regencies/Municipalities in Java and Bali. National Symposium on Accounting VI, Surabaya. October 16-17, 2013.

Adi, Priyo Hari (2007), The Relationship between Regional Economic Growth, Development Expenditure and Own-Source Revenue (a Study in Regencies and Municipalities in Java and Bali). Journal of Accounting and Finance of Public Sector Volume 08. No. 01. February, 2007. p. 1450-1465.

Adi, Priyo Hari (2008), The Relevance of Central Government Transfer with Local Tax Effort (a Study in District Administration and Municipalitis in Java)

Ahmad, Waluya Jati (2006), The Role of Local Tax and Levies on Own-Source Revenue (a Study in Regional Level II of East Java), Journal of Humanity, Vol. 2, 2006, Faculty of Economy, University of Muhammadiyah Malang.

Andirfa, Mulia (2009), The Influence of Economic Growth, Own-Source Revenue, Equalization Fund and other Legitimate Revenues on the Allocation of Capital Expenditure Budget (an Empirical Study in Regencies/Municipality in Aceh), Accounting Journal, Syiah Kuala Darussalam University, Banda Aceh.

Baskaran, T. (2012). The flypaper effect: evidence from a natural experiment with Hessian municipalities. Mimeo (University of Goettingen).

Badan Pusat Statistik Provinsi Bali (2012) PDRB, http://bali.bps.go.id/tabel.php?id=14 (2012 Pebruari 20)

Besley, T., S. Coate. (2003). Centralized versus decentralized provision of local public goods: a political economy approach. Journal of Public Economics, 87, 2611-2637 
Bird \& Smart (2001), "Intergovermental Fiscal Transfers: Some Lessons from International Experience”, Symposium on Intergovernmental Transfers in Asian Countries: Issues and Practices, Asian Tax and Public Policy Program, Hitosubashi University, Tokyo, Japan, February 2001

Christy, Fhino Andrea \& Adi, Priyo Hari (2009), The Relationship between General Allocation Fund, Capital Expenditure and the Quality of Human Development (IPM), Paper Presented in National Conference of UKWMS. Surabaya, October 10, 2009.

Darwanto \& Yulia Yustikasari (2007), The Influence f Economic Growth, Own-source Revenue and General Allocation Fund on the Allocation of CapitalExpenditure Budget. National Symposium of Accounting X. Makasar, University of Hasanudin, July 26-28, 2007.

De Mello, L. (1999). Fiscal Federalism and Government Size in Transition Economies: The Case of Moldova. Working Paper 99/176. Washington: IMF

Direktorat Jenderal Perimbangan Keuangan (2012) Dana Alokasi Umum, http://www.djpk.depkeu.go.id/datadjpk/51/(2012 Pebruari 20)

Ferdinand, A.T. (2006), Structural Equation Modeling in the Research on Application Management of Complicated Models in a Research for Thesis of Master Program and Dissertation of Doctorate Program, $4^{\text {th }}$ Edition, Publisher:

Ferdinand, A.T. (2011),Research Method on Management, a Research Guidance for Thesis (undergraduate and master program) and Dissertation in Management, $3^{\text {rd }}$ Editon, BP. UNDIP

Gan, Wang, Chen (2005), "Intergovermental Fiscal Transfer System a New Model from a Comparison Between Sweden and China". Kristianstad University.

Gamkhar, S., \& A. Shah. (2007). The Impact of Intergovernmental Fiscal Transfers: A Synthesis of the Conceptual and Empirical Literature. In: R. Boadway, A. Shah (eds.) Intergovernmental Fiscal Transfers: Principles and Practice.Washington: The World Bank

Hakim, Lukman. 2015. The Local Governments Ability to Develop Regional Potential Area Based on Seed and Competitiveness. International Journal of Academic Research. Mar 2015, Vol. 7 Issue 2B, pp. 71-75.

Halim, Abdul (2010), Regional Budget and Fiscal Stress (a Case Study in Provincial Budget in Indonesia). Journal of Economy and Business Indonesia 16 (4): 346-357

Harianto, David \& Adi, Priyo Hari (2007), The Relationship between General Allocation Fund, Capital Expenditure, Own-Source Revenue and Income per Capita. National Symposium on Accounting X. Makasar, Unhas, July 26-28, 2007.

Ismerdekaningsih \& Rahayu (2002), Analysis on the Relationship between Tax Revenue on Gross Domestic Product in Indonesia (Study in 1985-2000)

Knight, B. (2002). Endogenous Federal Grants and Crowd-Out of State Government Spending: Theory and Evidence from the Federal Highway Aid Program. American Economic Review, 92, 71-92

Kuncoro, Haryo (2007), Flypaper Effect Phenomenon in Financial Performance of Municipalities and District Administration in Indonesia, National Symposium on Accounting X. Makasar, Unhas, July 26-28, 2007.

Kuncoro, Mudrajat (2004), Otonomi dan Pembangunan Daerah, Penerbit Erlangga, Jakarta.

Kuncoro, Mudrajat (2010), Dasar-Dasar Ekonomika Pembangunan, Edisi Kelima, Penerbit UPP STIM YKPN, Yogyakarta. Principle of Development Economics. $5^{\text {th }}$ Edition.

Kusumadewi \& Rahman (2007), Flypaper Effect in General Allocation Fund (DAU) and Own-Source Revenue (PAD) on Regional Budget in Regencies/Municipalities in Indonesia. JAAI Vol. 11 No. 1, p. 67-80.

Laras, Wulan Ndadari \& Adi, Priyo Hari (2008), Perilaku Asimetris Pemerintah Daerah terhadap Transfer Pemerintah Pusat. The $2^{\text {nd }}$ National Conference UKWMS. Surabaya, 6 September 2008.

Legrenzi, Gabriella \& Costas Milas (2011), "Non-Linear and Asymmetric Adjusment The Local RevenueExpenditure Models: Some Evidence from The Italian Municipalities”, Working Paper, University of Milan.

Lewis, Blane D. (2008), “Some Empirical Evidence on New Regional Taxes and Charges in Indonesia”. Research Triangle Institute, North Carolina, USA.

Litschig, S. and K. Morrison (2009). Electoral effects of fiscal transfers: quasiexperimental evidence from local executive elections in Brazil, 1982-1988. Mimeo (Universitat Pompeu Fabra and Cornell University). 
Maiharyanti, Eva. (2010). The Influence of Local Revenue on Human Development Index and Capital Expenditure as Intervening Variables in District Administration and Municipalities in Nanggroe Aceh Darussalam, Thesis. University of North Sumatera, Medan.

Maimunah, Mutiara (2008), Flypaper Effect in General Allocation Fund (Dana Alokasi Umum-DAU) and Ownsource Revenue (Pendapatan Asli Daerah-PAD) on Capital Expenditure of Regencies/Municipalitis in Sumatera Island. Journal of Indonesia Accounting Research. Vol. 11, No. 1, January 2008, p. 37-51

Mardiasmo (2012), Regional Autonomy as an Effort to Strengthen Regional Economic Base. Paper Presented in Seminar on Extending People Economy.

Government Regulation of the Republic of Indonesia No. 24, 2005 on Governmental Accounting Standards

Prakosa, Kesit Bambang (2004), Analysis of the Influence of General Allocation Fund (Dana Alokasi Umum-DAU) and Own-source Revenue (Pendapatan Asli Daera-PAD) on the Prediction of Regional Budget (an Empirical Study in Central Java Province and DIY) JAAI Vol. 8, No. 2, 101-118.

Rokhaniyah, Siti \& Nugroho, Rudi, Muh (2011), Analysis of Flypaper Effect in the Expenditure of Municipalities and District Administration in Indonesia in 2006-2008. Fokus Ekonomi (FE), Agustus 2011, Hal. 100 - 113. Vol. 10, No. 2 ISSN: 1412-3851

Sidik, Machfud (2010 Optimization of Local Tax and Levies in order to Increase Fiscal Capability. Paper Presented in Scientific Oration. Bandung, 10 April 2010.

Sorribas-Navarro, P. (2011). Bailouts in a fiscal federal system: evidence from Spain. European Journal of Political Economy 27, 154-170.

Sugiyono (2011), Statistic for Research, Penerbit Alfabeta, Bandung.

Syahril (2011), The Influence of Own-source Revenue and Capital Expenditure on Human Development Index in Regencies/Municipalities in North Sumatera Province. Thesis. University of North Sumatera. Medan.

Law of Indonesia No. 28, 2009 on Local Tax and Levies

Law of Indonesia No. 33, 2004 on Financial Balance between Central Government and Local Government

Waluyo, Joko (2007 The Effect of Fiscal Decentralization on Economic Growth and Income Inequality between Regions in Indonesia. Parallel Session IA di Wisma Makara, Kampus UI-Depok, 12 Desember 2007

Wong, Jhon D. (2004), “The Fiscal Impact of Economic Growth and Development on Local Government Capacity”. Journal of Public Budgeting, Accounting \& Financial Management. Fall 1s6.3 hal 413-423.

Yudani, Ni Nengah (2008), Fiscal Decentralization in its Relationship with PAD and Development Budget in Bali Province, Thesis. Gadjah Mada University, Yogyakarta. 


\section{APPENDIX 1.}

\section{Causality Relationship Between Variables}

DAU, PAD, BM, Local Economic Growth, Income Per Capita, and IPM Standardized estimates
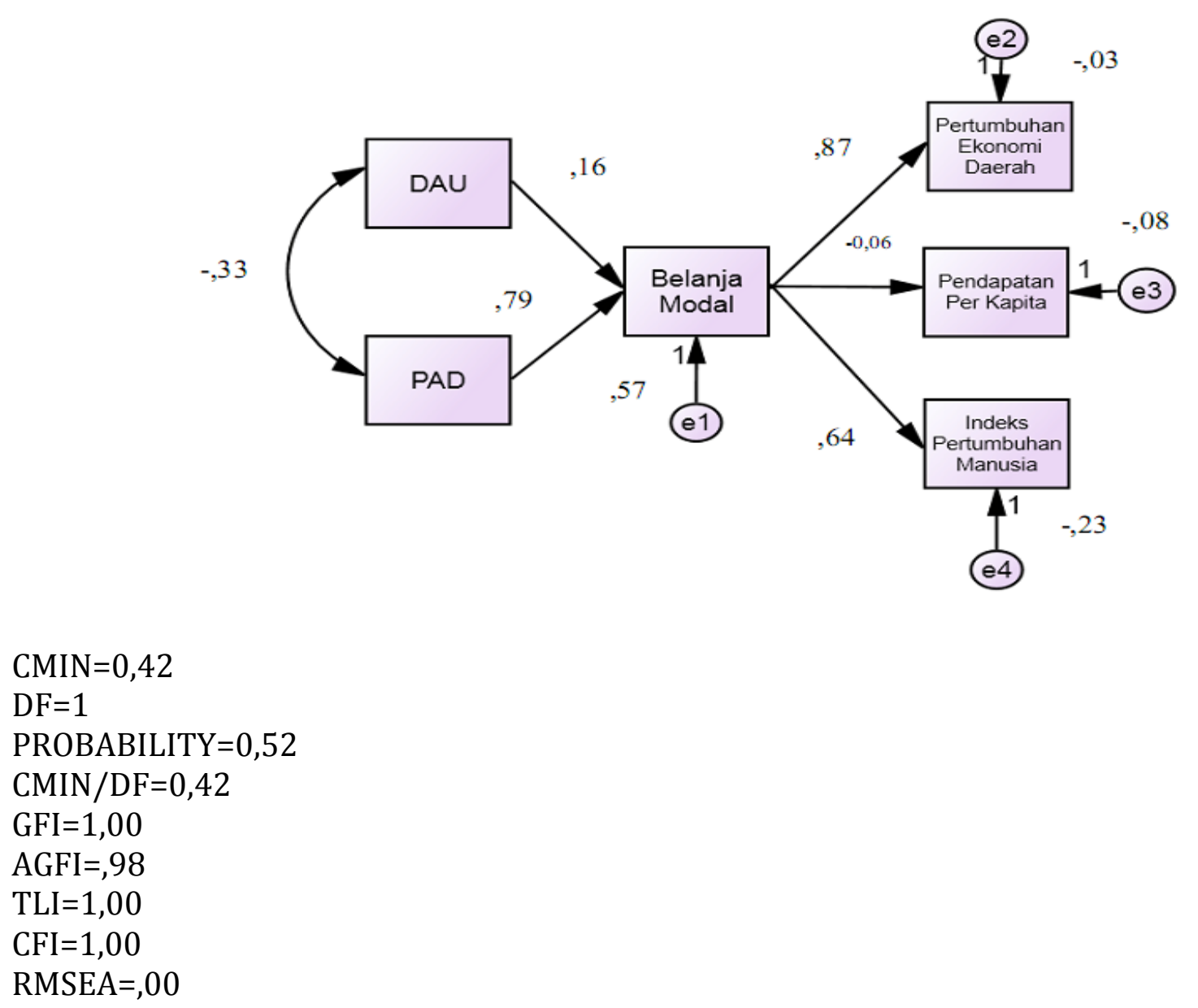

Source: Amos Statistical Data Processing Program For Windows Version 20.0 


\section{APPENDIX 2.}

Model Measurement Structure Unstandardized and Standardized Regression Weight

\begin{tabular}{|l|l|l|r|r|r|r|r|l|}
\hline & & & $\begin{array}{c}\text { Unstanda } \\
\text { rdized } \\
\text { Estimate }\end{array}$ & $\begin{array}{c}\text { Standar } \\
\text { dized } \\
\text { Estimate }\end{array}$ & S.E. & C.R. & P & $\begin{array}{c}\text { Explainati } \\
\text { on }\end{array}$ \\
\hline BM & $<---$ & DAU &, 13 &, 16 &, 04 & 3,63 & $* * *$ & Sig \\
\hline BM & $<---$ & PAD &, 25 &, 79 &, 02 & $\begin{array}{r}13,1 \\
6\end{array}$ & $* * *$ & Sig \\
\hline PED & $<---$ & BM &, 00 &, 87 &, 00 & 6,92 & $* * *$ & Sig \\
\hline PPK & $<---$ & BM &, 00 &,- 06 &, 00 & - &, 29 & non Sig. \\
\hline IPM & $<---$ & BM &, 00 &, 64 &, 00 & 4,99 & $* * *$ & Sig \\
\hline
\end{tabular}

Source: AMOS statistical data processing program for Windows version 20.0

\section{APPENDIX 3.}

Tabel Goodness of Fit

\begin{tabular}{|l|c|c|c|}
\hline \multicolumn{1}{|c|}{$\begin{array}{c}\text { Goodness of Fit } \\
\text { index }\end{array}$} & Cut of Value & Hasil Model & Keterangan \\
\hline Chi Square & $\begin{array}{c}\text { Diharapkan } \\
\text { kecil }\end{array}$ & 0,42 & good \\
\hline Relative Chi Square & $\leq 3,00$ & 0,42 & good \\
\hline Probability & $>0,05$ & 0,52 & good \\
\hline RMSEA & $\leq 0,08$ & 0,00 & good \\
\hline GFI & $\geq 0,90$ & 1,00 & good \\
\hline AGFI & $\geq 0,90$ & 0,98 & good \\
\hline CFI & $\geq 0,95$ & 1,00 & good \\
\hline TLI & $\geq 0,95$ & 1,00 & good \\
\hline
\end{tabular}

Source: AMOS statistical data processing program for Windows version 20.0 